\title{
THE HISTORY OF DEVELOPMENT AND THE PERSPECTIVES OF IMPLEMENTATION OF INNOVATIVE TECHNOLOGIES FOR THE ENVIRONMENTALLY SAFE USE OF WATER AND LAND RESOURCES IN UKRAINE AT THE BEGINNING OF THE 21st CENTURY
}

\author{
Nataliia Kovalenko $^{1^{*}}$, Svitlana Yehorova ${ }^{2}$ \\ ${ }^{1 *}$ Institute of History of Agrarian Science, Education and Technique of NSAL NAAS, Ukraine; \\ ${ }^{2}$ Institute of Water Problems and Land Reclamation of NAAS, Ukraine; \\ *Corresponding Author Nataliia Kovalenko, e-mail: BoikoNP@ukr.net;
}

Received November 2021; Accepted December 2021; Published January 2022;

DOI: https://doi.org/10.31407/ijees12.110

\begin{abstract}
The article finds that at the beginning of the 21 st century the implementation of innovative technologies for the environmentally safe use of water and land resources in Ukraine has developed significantly and has great perspectives, especially in climate change. The Ukrainian scientists have created and improved economic and mathematical models and computer programs to optimize the functioning of agroecosystems in different soil and climatic conditions of Ukraine. The determining factor for expanding the implementation of innovative technologies in Ukraine was the cooperation of Ukrainian scientists with foreign scientists. An example of such cooperation was the theoretical confirmation by Ukrainian and Chinese scientists of the effectiveness of simulation and dynamic computer models developed by American scientists. It was found that due to the practical application of such models in different soil and climatic conditions of Ukraine and China, a significant contribution was made to the further development and improvement of innovative technologies to reduce soil erosion degradation. These computer models are efficient due to the extraordinary dynamism in time and variability in space and have great perspectives for future implementation. The priority direction of research of Ukrainian scientists for environmentally safe use of water and land resources with the use of geoinformation technologies and methods of space monitoring is proved. These innovative technologies were aimed at creating and widely using powerful databases and knowledge, as well as cartographic products for environmental and reclamation monitoring of water and land resources in different soil and climatic conditions of Ukraine - Steppe, Forest-Steppe and Polissya. It was found that Ukrainian scientists have widely used the international experience of managing the transformation of reclamation systems as a result of the international Ukrainian-Dutch project «Watermuk». It is concluded that the use of these innovative technologies in different soil and climatic conditions of Ukraine has provided the necessary level of soil protection from erosion, environmentally safe use of water and land resources, high productivity and ecological balance of the environment. Which will expand the perspectives for the implementation of optimal agroecosystems in the world, especially in climate change.
\end{abstract}

Key words: development, improvement, environmentally safe use, water and land resources, geoinformation technologies, methods of space monitoring, perspectives of implementation. 